\title{
Cooperação Técnica com o Japão
}

\author{
Ten. Cel. Francisco Antônio Mondadori Vallet
}

\section{Apresentação:}

A JICA, Japan International Cooperation Agency, é o órgão que está vinculado ao Ministério dos Negócios Estrangeiros do Governo do Japão, responsável pela implementação dos programas e projetos de cooperação técnica do Japão com países em desenvolvimento. Cooperação esta que objetiva colaborar com os esforços desses páses, no sentido da promoção do crescimento econônico e melhoria das condições de vida de suas populações. Para tanto, a JICA possui escritórios em mais de 80 páses.

As atividades da JICA inserem-se no âmbito da "Oficial Development Assistance ODA" Assistência Oficial para o Desenvolvimento do Governo Japonês. A cooperação prestada especialmente para o Brasil é regulada pelo acordo básico de cooperação técnica Brasil/Japão, assinado em 1970.

A JICA atua nas seguintes modalidades básicas de cooperação;

a) Envio de Peritos Japoneses;

b) Treinamento no Japão;

c) Doação de Equipamentos;

d) Cooperação Técnica Tipo Projeto;

e) Mini Projeto e Cooperação de Pesquisa;

f) Estudos para o Desenvolvimento;

g) Programa de Treinamento para Tercciros Países (TCTP);

O Programa de Treinamento para Terceiros Países consiste na realização de cursos de treinamento para técnicos de países que possuam características sociais, culturais e de idiomas semellantes (no caso do Brasil, os países da Amética Latina e da África de língua portuguesa).

'Mestre em Administração Pública - UFRGS 2000, Chefe do e Eustado Maior do Comando do Corpo de Bombeiros da Brigada Militar do Estado do Rio Grande do Sul, Professor de Administração na Academia de Policia Militar, UFRGS, ULBRA e PUC. Presidente da Associação Sul Brasileira de Bolsistas do Japảo (RS e SC). 
Os cursos são ministrados pelas instituições brasileiras, sendo que as despesas de viagem e estada dos bolsistas no Brasil são custeadas com recursos da JICA.

\section{Situação}

No Brasil, em relação a atividade de bombeiros, a JICA já firmou dois convênios, sendo um na modalidade "Projeto de Academia de Bombeiros" e outro de "Mini Projeto de Laboratório de Perícia de Incêndios", ambos já implantados e em funcionamento no Distrito Fiederal, desde 1983.

No Rio Grande do Sul, através da JICA, alguns servidores militares já foram especializados nas diversas áreas de atuação da Brigada Militar, como policiamento ambiental, atividades de salvamento, prevenção, socorrismo, investigação de sinistros e combate a incêndios.

Desses cursos, tesulraram diversos benefícios. Dentre eles, a adoção de técnicas atualizadas nas várias atividades de bombeiros, bem como os fundamentos para a implementação da Escola de Bombeiros, a qual forma e especializa Bombeiros Militares es integrantes dos serviços civis auxiliares de bombeiro, desde 1989.

Ainda que o ensino e o treinamento dos bombeiros no Rio Grande do Sul não esteja ocorrendo da forma ideal, já possui uma estrururação curricular e um conjunto de conhecimentos suficientes para afirmar que o Corpo de Bombeiros do Rio Grande do Sul, em algumas atividades, pode partilhar seus conhecimentos com outros Corpos de Bombeiros, tanto repassando como recebendo essas informações.

Nesre sentido, ao longo de mais de uma década, tem sido buscado parcerias e apoios externos, por intermédio da Escola de bombeiros e Corpo de Bombeiros da Brigada Militas.

A JICA tem oferecido vagas para cursos e rreinamento no Japão porém, de fato, nenhuma ação concreta foi realizada com êxito para formalizar um convênio entre o Corpo de Bombeiros da Brigada Militar e o Corpo de Bombeiros do Japão.

Recentemente, no mês de abril, quando da visita ao Rio Grande do Sul para participar da solenidade de abertura de mais um Curso de Treinamento para Terceiros Países (CTTP), do T'RENSURB, dois integrantes da JICA/SP, Sr. AUGUSTO HIROMU EMORI e Sr. HIROSHI SATO, (sendo este Diretor Adjunto), manifestaram interesse em realizar convênio com o Corpo de Bombeiros da Brigada Militar na modalidade CTTP. Na ocasião ofereceram os documentos necessários e visitaram a Escola de Bombeiros da Brigada Militar, ficando com excelente impressão sobre as condições e possibilidades para implementat essa modalidade de convênio.

Assim, apresenta-se como opottunidade no sentido de proceder ao encaminhamento dos documentos necessários para a realização do projeto, conforme formulários da JICA, com a finalidade de obrer a manifestação daquela Agência de Cooperação do Japão, para o convênio de cooperação técnica na modalidade Cursos de Treinamento de Terceiros Países, nos moldes dos já realizados pelo TRENSURB e pela PUC/RS, bá quase uma década.

O prazo de entrega dos projetos na Agência Brasileira de Cooperação (ABC) do Ministério de Relaçôes Exteriores (MRE), expira no mês de março de cada ano, sendo que 
após análise, aquela agência remete à JICA, no mês de junho, os projetos que estiverem elaborados conforme os regramentos adequados.

Há ainda outros projetos que a JICA participou, relacionados com a preservação ambiental, como os vinculados a Usina Termoelétrica de Candiota e do projeto Mar de Dentro, referente a preservação ambiental da costa lacustre e marituma gaúcha.

A ASBBJ, Associação Sul Brasileira de Bolsistas do Japão participa dessas atividades de cooperação, principalmente ao que se refere ao envio de técnicos especialistas no curso de aperfeiçoamento que se realiza no Japão, mediante a divulgação de formulários de bolsas de estudos no Japão, orientação e apoio aos candidatos das diversas instituições, tanto públicas como privadas, universidades, instituições culturais bem como pesquisadores e interessados na cultura japonesa, em geral. É a entidade brasileira que mais bolsistas tem enviado ao Japão ao longo dos últimos vinte anos.

Ainda, realiza reuniões técnicas, sociais e culturais com freqüência de três a quatro reunióes por ano, quando propicia o encontro de seus sócios e pessoas relacionadas coma cultura e tecnologia japonesa.

Através de publicações, a ASBBJ contribui no fomento à cultura japonesa e da tecnologia apreendidos pelos bolsistas durante a estada no Japão através da bolsa da JICA.

Sua atividade é integralmente volun tária e pretende ser uma forma de retribuir toda a atenção recebida durante os cursos no japão, bem como fortalecer o convivio e intercâmbio técnico e culrural entre os bolsistas e suas instituiçôes, mediante projetos e seminátios técnicos. A aplicação dos conhecimentos obtidos no Japão visa aperfeiçoar as atividades desenvolvidas nas suas empresas, faculdades e instituições, com expressiva aceitação e resultados satisfatórios. 